\title{
Stormy weather: a retrospective analysis of demand for emergency medical services during epidemic thunderstorm asthma
}

\author{
Emily Andrew, ${ }^{1,2}$ Ziad Nehme, ${ }^{1,2,3}$ Stephen Bernard, ${ }^{1,2,4}$ Michael J Abramson, ${ }^{2}$ Ed Newbigin, ${ }^{5}$ \\ Ben Piper, ${ }^{6}$ Justin Dunlop, ${ }^{7}$ Paul Holman, ${ }^{7}$ Karen Smith ${ }^{1,2,3}$
}

${ }^{1}$ Centre for Research and

Evaluation, Ambulance Victoria, Doncaster, VIC 3108, Australia

3108

${ }^{2}$ Department of Epidemiology and Preventive Medicine,

Monash University, Melbourne, VIC 3004, Australia

${ }^{3}$ Department of Community Emergency Health and

Paramedic Practice, Frankston, VIC 3199, Australia

${ }^{4}$ Intensive Care Unit, The Alfred Hospital, Melbourne, VIC 3004 , Australia

${ }^{5}$ School of BioSciences, University of Melbourne, Melbourne, VIC 3052, Australia

${ }^{6}$ Emergency Services

Telecommunications Authority, Burwood East, VIC 3151, Australia 3151

${ }^{7}$ Emergency Management Unit, Ambulance Victoria, Melbourne, VIC 3000, Australia

Correspondence to:

Emily Andrew

emily.andrew@ambulance.vic.

gov.au

Additional material is published online only. To view please visit the journal online.

Cite this as: $B M J$ 2017;359:j5636 http://dx.doi.org/10.1136/bmij.5636

Accepted: 27 November 2017

\section{ABSTRACT}

OBJECTIVES

To describe the demand for emergency medical assistance during the largest outbreak of thunderstorm asthma reported globally, which occurred on 21 November 2016.

\section{DESIGN}

A time series analysis was conducted of emergency medical service caseload between 1 January 2015 and 31 December 2016. Demand during the thunderstorm asthma event was compared to historical trends for the overall population and across specific subgroups.

SETTING

Victoria, Australia.

\section{MAIN OUTCOME MEASURES}

Number of overall cases attended by emergency medical services, and within patient subgroups. RESULTS

On 21 November 2016, the emergency medical service received calls for 2954 cases, which was 1014 more cases than the average over the historical period. Between $6 \mathrm{pm}$ and midnight, calls for 1326 cases were received, which was 2.5 times higher than expected. A total of 332 patients were assessed by paramedics as having acute respiratory distress on 21 November, compared with a daily average of 52 during the historical period. After adjustment for temporal trends, thunderstorm asthma was associated with a $42 \%$ (95\% confidence interval $40 \%$ to $44 \%$ ) increase in overall caseload for the emergency medical service and a $432 \%$ increase in emergency medical attendances for acute respiratory distress symptoms. Emergency transports to hospital increased by $17 \%$ (16\% to $19 \%$ ) and time critical referrals from general

\section{WHAT IS ALREADY KNOWN ON THIS SUBJECT}

Thunderstorm asthma is a rare phenomenon whereby a surge in patients with acute respiratory illness occurs after a thunderstorm.

It increases pressure on health services such as primary care facilities and emergency departments.

\section{WHAT THIS STUDY ADDS}

We found that the largest globally reported outbreak of thunderstorm asthma was associated with a $42 \%$ increase in the overall caseload of emergency medical services and a $432 \%$ increase in emergency attendances for acute respiratory distress symptoms after adjustment for temporal trends.

Demand management strategies were insufficient to manage such a widespread and rapid onset event, with ambulance resources quickly depleted.

The incidence of out-of-hospital cardiac arrest and pre-hospital deaths increased by $82 \%$ and $41 \%$, respectively. practitioners increased by $47 \%$ ( $21 \%$ to $80 \%)$. Large increases in demand were seen among patients with a history of asthma and bronchodilator use. The incidence of out-of-hospital cardiac arrest increased by $82 \%(67 \%$ to $99 \%)$ and pre-hospital deaths by $41 \%$ (29\% to $55 \%)$.

\section{CONCLUSIONS}

An unprecedented outbreak of thunderstorm asthma was associated with substantial increase in demand for emergency medical services and pre-hospital cardiac arrest. The health impact of future events may be minimised through use of preventive measures by patients and predictive early warning systems.

\section{Introduction}

Weather and climatic conditions have been associated with exacerbation of various health conditions, including cardiovascular diseases, mental health and sleep disorders, and infectious diseases. ${ }^{1}$ Thunderstorm asthma is a rare phenomenon, thought to occur when a source of allergen, typically pollen, and appropriate weather conditions, such as a thunderstorm, combine to trigger severe asthma among susceptible people in the vicinity. ${ }^{2}$ Pollen grains are too large to enter the lower respiratory tract; rain is thought to cause the grains to expand and burst, discharging their allergenic contents as fine respirable particles. ${ }^{3-5}$ Asthma symptoms, such as coughing and wheezing, arise when sensitised patients breathe in these particles, which inflame the lining of airways. ${ }^{6}$ Thunderstorm asthma can affect patients with or without a history of asthma, but patients who experience hay fever are at increased risk. ${ }^{6-9}$

On 21 November 2016, parts of Victoria, Australia, especially the capital city of Melbourne, encountered a thunderstorm asthma health emergency. The event saw a sudden and unprecedented increase in demand on the emergency medical service and hospital emergency departments by patients with acute respiratory distress. Several epidemics of thunderstorm asthma have been reported in Australia ${ }^{9} 10$ and internationally, ${ }^{11-14}$ commonly in regions susceptible to high aeroallergen loads (table 1). ${ }^{8}$ Before the event in Victoria, the number of affected people ranged between 40 and 2000. But the scale of this event exceeded all previous reports, with approximately 13000 presentations to hospitals in Victoria, more than 3000 of which were related to respiratory problems. ${ }^{29}$ The surge in demand for emergency medical services surpassed that of any previous event in Victoria, including the bushfires and heatwaves of $2009 .^{27}$ 


\begin{tabular}{|c|c|c|c|c|c|c|}
\hline Location & Month, year & Season & $\begin{array}{l}\text { No of patients affected } \\
\text { after thunderstorm }\end{array}$ & Duration & $\begin{array}{l}\text { Expected No of } \\
\text { patients over } \\
\text { reported duration }\end{array}$ & $\begin{array}{l}\text { Proposed } \\
\text { allergen }\end{array}$ \\
\hline Birmingham, UK ${ }^{15}$ & July, 1983 & Summer & $\begin{array}{l}106 \text { presentations to } 8 \text { emergency departments } \\
\text { for asthma or other respiratory disorders }\end{array}$ & 48 hours & 2-20 a day & Fungal spores \\
\hline Melbourne, Australia ${ }^{16}$ & $\begin{array}{l}\text { November, } \\
1984\end{array}$ & Spring & $\begin{array}{l}85 \text { presentations to } 1 \text { emergency department } \\
\text { for asthma }\end{array}$ & $\begin{array}{l}\text { Up to } 24 \\
\text { hours }\end{array}$ & NR & NR \\
\hline Nottingham, UK ${ }^{17}$ & June, 1984 & Summer & $\begin{array}{l}19 \text { presentations to } 1 \text { emergency department for } \\
\text { acute asthma }\end{array}$ & 7 hours & $<6$ a day & Fungal spores \\
\hline \multirow[t]{2}{*}{ Melbourne, Australia ${ }^{10}$} & \multirow[t]{2}{*}{$\begin{array}{l}\text { November, } \\
1987\end{array}$} & \multirow[t]{2}{*}{ Spring } & $\begin{array}{l}154 \text { presentations to major emergency depart- } \\
\text { ments for asthma }\end{array}$ & 12 hours & 26 & \multirow[t]{2}{*}{ NR } \\
\hline & & & 22 EMS transports for asthma & 12 hours & 2 & \\
\hline \multirow[t]{2}{*}{ Melbourne, Australia ${ }^{10}$} & \multirow[t]{2}{*}{$\begin{array}{l}\text { November, } \\
1989\end{array}$} & \multirow[t]{2}{*}{ Spring } & $\begin{array}{l}277 \text { presentations to major emergency depart- } \\
\text { ments for asthma }\end{array}$ & 12 hours & 26 & \multirow[t]{2}{*}{ Grass pollen } \\
\hline & & & 44 EMS transports for asthma & 12 hours & 2 & \\
\hline \multirow[t]{2}{*}{ Tamworth, Australia ${ }^{18}$} & \multirow[t]{2}{*}{$\begin{array}{l}\text { November, } \\
1990\end{array}$} & \multirow[t]{2}{*}{ Spring } & $\begin{array}{l}110 \text { presentations to } 2 \text { emergency departments } \\
\text { for acute asthma }\end{array}$ & 5 days & $<5$ a day & \multirow[t]{2}{*}{ Grass pollen } \\
\hline & & & 123 GP presentations for acute asthma & 5 days & NR & \\
\hline \multirow[t]{2}{*}{ London, UK ${ }^{1920}$} & \multirow[t]{2}{*}{ June, 1994} & \multirow[t]{2}{*}{ Summer } & $\begin{array}{l}640 \text { emergency department presentations for } \\
\text { asthma or airways disease }\end{array}$ & 30 hours & 66 & \multirow[t]{2}{*}{ Grass pollen } \\
\hline & & & 536 calls for asthma to out-of-hours GP service & 48 hours & 135 & \\
\hline Wagga Wagga, Australia9 & October, 1997 & Spring & $\begin{array}{l}215 \text { presentations to a major emergency depart- } \\
\text { ment for asthma }\end{array}$ & 36 hours & NR & Grass pollen \\
\hline Calgary, Canada ${ }^{13}$ & July, 2000 & Summer & $\begin{array}{l}157 \text { presentations to } 3 \text { emergency departments } \\
\text { for asthma or shortness of breath }\end{array}$ & 48 hours & 17 & $\begin{array}{l}\text { Fungal spores, } \\
\text { pollen }\end{array}$ \\
\hline Cambridge, $\mathrm{UK}^{21}$ & July, 2002 & Summer & $\begin{array}{l}57 \text { emergency department presentations or hos- } \\
\text { pital admissions to } 1 \text { hospital for acute asthma }\end{array}$ & 48 hours & NR & Fungal spores \\
\hline Al-Khobar, Saudi Arabia ${ }^{22}$ & $\begin{array}{l}\text { November, } \\
2002\end{array}$ & Autumn & $\begin{array}{l}\text { Spike in emergency department presentations at } \\
1 \text { hospital for acute asthma (exact number not } \\
\text { specified) }\end{array}$ & $\begin{array}{l}\text { Up to } 24 \\
\text { hours }\end{array}$ & NR & NR \\
\hline Melbourne, Australia ${ }^{23}$ & $\begin{array}{l}\text { November, } \\
2003\end{array}$ & Spring & $\begin{array}{l}70 \text { paediatric emergency department presenta- } \\
\text { tions for asthma }\end{array}$ & 24 hours & 21 & Grass pollen \\
\hline Naples, Italy ${ }^{24}$ & June, 2004 & Summer & $\begin{array}{l}7 \text { presentations to } 1 \text { emergency department for } \\
\text { asthma }\end{array}$ & 30 minutes & NR & Pollen \\
\hline South East England, UK ${ }^{25}$ & June, 2005 & Summer & $\begin{array}{l}400 \% \text { increase in calls to NHS Direct for } \\
\text { "difficulty breathing" and a } 50 \% \text { increase in GP } \\
\text { out-of-hours attendances }\end{array}$ & $\begin{array}{l}\text { Up to } 24 \\
\text { hours }\end{array}$ & NR & NR \\
\hline Puglia, Italy ${ }^{26}$ & May, 2010 & Spring & $\begin{array}{l}20 \text { presentations to } 1 \text { emergency department } \\
\text { for asthma }\end{array}$ & 14 hours & $2-3$ a day & Olive pollen \\
\hline Melbourne, Australia ${ }^{7}$ & $\begin{array}{l}\text { November, } \\
2010\end{array}$ & Spring & $\begin{array}{l}<40 \text { presentations to } 1 \text { tertiary emergency } \\
\text { department }\end{array}$ & 24 hours & $<5$ & Grass pollen \\
\hline London, UK ${ }^{11}$ & July, 2013 & Summer & $\begin{array}{l}40 \text { emergency department presentations for } \\
\text { asthma/wheeze/difficulty breathing }\end{array}$ & 24 hours & $15-20$ & NR \\
\hline Ahvas, $\operatorname{Iran}^{14}$ & $\begin{array}{l}\text { November, } \\
2013\end{array}$ & Autumn & $\begin{array}{l}\text { Sudden rise in emergency department presenta- } \\
\text { tions for acute bronchospasm attacks (exact } \\
\text { number not specified) }\end{array}$ & NR & NR & Air pollution \\
\hline \multirow[t]{3}{*}{$\begin{array}{l}\text { Melbourne and Geelong, } \\
\text { Australia }^{27-29}\end{array}$} & \multirow[t]{3}{*}{$\begin{array}{l}\text { November, } \\
2016\end{array}$} & \multirow[t]{3}{*}{ Spring } & $\begin{array}{l}9909 \text { emergency department presentations to } \\
\text { public hospitals; } 2973 \text { for respiratory problems; } \\
476 \text { excess asthma related hospital admissions } \\
\text { over } 30 \text { hours }\end{array}$ & 48 hours & $\begin{array}{l}6266 \text { presenta- } \\
\text { tions; } 453 \text { for res- } \\
\text { piratory problems }\end{array}$ & \multirow{3}{*}{ Grass pollen } \\
\hline & & & $\begin{array}{l}313 \text { nurse on-call calls for breathing/respiratory/ } \\
\text { allergy problems; }\end{array}$ & 24 hours & 63 & \\
\hline & & & $\begin{array}{l}332 \text { patients with paramedic assessed acute } \\
\text { respiratory distress }\end{array}$ & 24 hours & 52 & \\
\hline
\end{tabular}

*Includes epidemic thunderstorm asthma events reported in the scientific literature or published reports. Events reported in newspaper articles only are excluded. EMS=emergency medical service; $\mathrm{GP}=$ general practitioner; $\mathrm{NR}=$ not reported.

A previous review found several studies describing the effects of thunderstorm asthma on emergency department and primary care services. ${ }^{8}$ But limited evidence exists on the effects on the wider health system, including emergency medical services. ${ }^{8}$ To optimise the emergency medical response to future emergencies, we need to understand the direct effects of thunderstorm asthma on patients, caseloads, and associated deaths. We describe the demand on Ambulance Victoria, the state-wide emergency medical service in Victoria, Australia, during the thunderstorm asthma emergency.

\section{Methods}

\section{Study design}

We conducted a retrospective review and time series analysis of the emergency caseload in Victoria, Australia, between 1 January 2015 and 31 December 2016. We excluded pre-booked non-emergency patient transport cases. This study was approved by Monash University Human Research Ethics Committee (\#7739).

\section{Setting}

The state of Victoria has a population of 6.07 million and spans almost 92000 square miles $\left(238000 \mathrm{~km}^{2}\right)$. 
The capital city, Melbourne, sees an average of 10 thunderstorms a year. Calls for emergency medical assistance are triaged by the Emergency Services Telecommunications Authority using the Medical Priority Dispatch System. The Emergency Services Telecommunications Authority is the state government statutory authority responsible for providing multiagency emergency service telecommunications, including taking calls and dispatching. Ambulance Victoria has two tiers, with both advanced life support and intensive care paramedics responding to medical emergencies according to a pre-defined resource allocation matrix. Firefighters with basic life support training and community volunteer teams also respond to some time critical emergencies in select areas of the state. All paramedics can give intramuscular epinephrine and ventilation with a supraglottic airway to patients with severe respiratory distress, and intensive care paramedics can perform endotracheal intubation and give intravenous epinephrine in such cases. All paramedics can give intravenous epinephrine to cases of cardiac arrest.

Ambulance Victoria also operates a referral service where low acuity emergency calls undergo secondary telephone triage by paramedics or nurses. ${ }^{30}$ This might result in emergency ambulance dispatch, referral to an alternative service (such as nonemergency transport or general practitioner), or self care advice, including advice to self present to an emergency department.

Victoria has a health emergency response plan that outlines the arrangements for coordinating the response to emergency incidents. ${ }^{31}$ On 21 November 2016 the state activated elements of the health emergency response plan and implemented escalation processes. It used several demand management strategies during the surge, including cancelling emergency ambulance dispatch to low acuity cases, cancelling pre-booked non-emergency cases, recalling staff, dispatching regional resources to metropolitan cases, dispatching first responders with basic life support training, and using police officers to conduct welfare checks. Ambulance Victoria stopped its usual secondary triage processes, and staff were used to reprioritise emergency cases. Operational paramedics were permitted to complete paper rather than electronic patient care records to make them available to respond to pending cases sooner.

\section{Data sources and definitions}

We sourced caseload data from the Ambulance Victoria data warehouse and telephony and resource allocation data from the Emergency Services Telecommunications Authority. The Ambulance Victoria data warehouse also contains data from electronic patient care records that are completed by paramedics at the conclusion of every case. We extracted cases of confirmed out-ofhospital cardiac arrest from the Victorian Ambulance Cardiac Arrest Registry. This registry collects clinical and operational data for all out-of-hospital cardiac arrests attended by Ambulance Victoria in accordance with Utstein recommendations ${ }^{32}$ and has been described in detail elsewhere. ${ }^{33}$

We sourced weather data from the Australian Bureau of Meteorology using observations recorded at Melbourne Olympic Park (1.6 miles $(2.5 \mathrm{~km})$ east of city centre). We sourced air quality data from the Environment Protection Authority of Victoria, with all observations recorded at Brooklyn (6.2 miles (10 $\mathrm{km}$ ) west of city centre), except for particulate matter smaller than $2.5 \mu \mathrm{m}$ in diameter $\left(\mathrm{PM}_{2.5}\right)$, which was recorded at Footscray (3.1 miles $(5 \mathrm{~km})$ west of city centre). We sourced daily pollen counts from the School of Biosciences at the University of Melbourne. We collected pollen as previously described ${ }^{34}$ and reported it as the average concentration of grass pollen per cubic metre of air for the preceding 24 hours to 4 $\mathrm{pm}$.

Cases with multiple emergency phone calls were counted as a single case. Patients with a paramedic assessment of acute respiratory distress included those with asthma or shortness of breath. We coded preexisting conditions into a history of asthma or other respiratory conditions, including chronic bronchitis, emphysema, chronic obstructive pulmonary disease, pulmonary oedema, croup, apnoea, and bronchiectasis. We categorised asthma preventer and bronchodilator drugs according to the National Asthma Council of Australia guidelines. ${ }^{35}$

\section{Statistical analyses}

Baseline characteristics are presented as frequencies and proportions, mean (standard deviation) or median (interquartile range), as appropriate. We estimated the 99th centile of cases over the two year study period using linear interpolation. We compared groups using the $\chi^{2}$, Fischer's exact, $t$ test, or Mann-Whitney $\mathrm{U}$ test, as appropriate. We compared the baseline characteristics of patients seen by Ambulance Victoria during the thunderstorm asthma event (6 pm to 11 $59 \mathrm{pm}$ on 21 November 2016) with those seen during the same hours on the three previous consecutive Mondays.

To investigate the effect of thunderstorm asthma on daily caseload of Ambulance Victoria after adjustment for temporal trends, we used negative binomial time series regression analyses with distributed lags. We included all cases occurring between 1 January 2015 and 31 December 2016. Results are presented as incident rate ratios and $95 \%$ confidence intervals. Models were adjusted for day of week, month, and long term trend. The thunderstorm asthma event was included in the model as a dichotomous term, with the entire day of 21 November 2016 defined as the thunderstorm asthma period. We included three lag days in models to assess residual effects. We calculated the cumulative effect of thunderstorm asthma as the sum of the effect on the day of the event and the three lag days. We conducted time series analyses across patient subgroups and local government areas. We conducted a sensitivity analyses in which all emergency ambulance attendances during the 
thunderstorm asthma period with missing patient data were assumed to involve respiratory distress $(n=250)$.

We performed all analyses using Stata 14 software (StataCorp. 2015. Stata Statistical Software: Release 14. College Station, TX). We considered two sided $P$ values less than 0.05 to be statistically significant.

\section{Patient involvement}

No patients were involved in setting the research question or outcomes measures, nor were they involved in developing plans for design or implementation of the study. No patients were asked to give advice on interpretation or writing up of results.

\section{Results}

Weather and aerobiology

21 November 2016 was Melbourne's hottest spring day with a maximum temperature of $35^{\circ} \mathrm{C}$. Gusty northerly winds resulted in a reading of 102 grass pollen grains/ $\mathrm{m}^{3}$ of air for the 24 hours to $4 \mathrm{pm}$. This meant the pollen count was classified as extreme ( $\geq 100$ grains $/ \mathrm{m}^{3}$ ), with susceptible people having a high risk of severe allergic rhinitis. ${ }^{36}$

A north-south line of thunderstorms developed west of Melbourne in the mid-afternoon and produced severe westerly wind gusts of $37 \mathrm{mph}(60 \mathrm{~km} / \mathrm{h})$ or more. The line of storms moved eastwards across Melbourne between $5 \mathrm{pm}$ and $630 \mathrm{pm}$. The storm passage was marked by a sharp drop in temperature, an increase in relative humidity, and a rapid change in wind direction from northerly to westerly (fig 1). The change in wind direction led to a rise in $\mathrm{PM}_{10}$ in the air, peaking at $191 \mu \mathrm{g} / \mathrm{m}^{3}$. Rainfall up to $1-4 \mathrm{~mm}$ was recorded across Melbourne after the wind change, and the levels of grass pollen and $\mathrm{PM}_{10}$ in the air both fell as winds eased during the evening from light west to south westerly. The average daily grass pollen reading for Melbourne on 22 November was classified as low (19 grains $\left./ \mathrm{m}^{3}\right)$. Grass pollen levels remained low $(<20$ grains $/ \mathrm{m}^{3}$ ) over the next few days.

\section{Hourly caseload}

Figure 1 shows the hourly emergency caseload, with a sharp increase in caseload after the storm and wind change. Between $7 \mathrm{pm}$ and $8 \mathrm{pm}$, the caseload reached 297 cases, corresponding to 2.43 times the 99 th centile caseload of the two year study period (122 cases). Between $6 \mathrm{pm}$ and midnight, emergency services received calls for 1326 cases. As such, the caseload was 2.50 times the average ( 530 cases), equating to almost 800 additional cases. The caseload was so extreme that no ambulance could be dispatched to more than 500 cases; these were closed through paramedic telephone assessment. The caseload fell back down to 65 cases between 7 am and 8 am the next day, which was under the 99 th centile of the comparator period (77 cases).

\section{Patient characteristics}

The characteristics of patients attended by an emergency ambulance between $6 \mathrm{pm}$ and midnight on 21 November were compared with patients seen during the same hours on the three previous Mondays (table 2). Only patients with an electronic patient care record were included (thunderstorm asthma period: $82.3 \%$ (615 of 747) of emergency attendances; comparator period: $92.8 \%$ (1111 of 1197)). Patients seen in the thunderstorm asthma period were significantly younger than in the comparator period. Almost half of all patients reported a history of asthma, but $26.4 \%$ (156 of 590) and 1.4\% (8 of 590) were recorded as taking only an asthma bronchodilator or preventive medication, respectively. Almost half of the patients seen in the thunderstorm asthma period had acute respiratory distress when assessed by paramedics.

Thunderstorm asthma period comprised $6 \mathrm{pm}$ to11 $59 \mathrm{pm}$ on 21 November 2016; comparator period comprised $6 \mathrm{pm}$ to $1159 \mathrm{pm}$ on the three Mondays before. Proportions exclude missing data. $\mathrm{CI}=$ confidence interval; $\mathrm{SD}=$ standard deviation.

Seventeen out-of-hospital cardiac arrests were recorded during the event (supplementary table S1). More than half of these $(n=9)$ were presumed to have a respiratory cause $(52.9 \%)$, compared with none of the 15 recorded in the comparator period $(\mathrm{P}<0.001)$. Eight $(47.1 \%)$ patients had a history of asthma, compared with three $(20 \%)$ in the comparator period. See supplementary table S2 for the characteristics of patients with a paramedic assessment of acute respiratory distress.

\section{Effects of thunderstorm asthma on emergency services}

The emergency medical service handled 2954 cases on 21 November and 2493 cases the next day, compared with an average of 1940 cases over the comparator period (fig 2). After adjusting for temporal tends, thunderstorm asthma was associated with a $41.7 \%$ (95\% confidence interval $39.6 \%$ to $43.9 \%$ ) increase in caseload on 21 November (supplementary figure S1). The cumulative effect of the event, accounting for three additional lag days, was an increase in caseload of $96.6 \%$ (86.3\% to $107.4 \%$ ). Emergency transports to hospital on 21 November rose by $17.3 \%(15.6 \%$ to $19.1 \%$ ), and time critical referrals from general practitioners rose by $47.1 \%$ (20.5\% to $79.6 \%)$.

On 21 November, emergency services received calls for 774 cases with breathing problems, and 332 cases had acute respiratory distress on paramedic assessment (supplementary figure S2). After adjustment, thunderstorm asthma was associated with a $337.2 \%$ (313.3\% to $362.5 \%)$ increase in calls for breathing problems (supplementary figure S3A) and a $432.3 \%$ (398.4\% to $468.5 \%)$ rise in patients with acute respiratory distress (supplementary figure $\mathrm{S} 3 \mathrm{~B})$. In a sensitivity analysis accounting for missing data, we found that the increase in acute respiratory distress could have been as high as $644.0 \%$ (596.7\% to $694.6 \%$ ).

Effect of thunderstorm asthma on patient subgroups As previously, only patients with an electronic patient care record were included. After adjustment, 

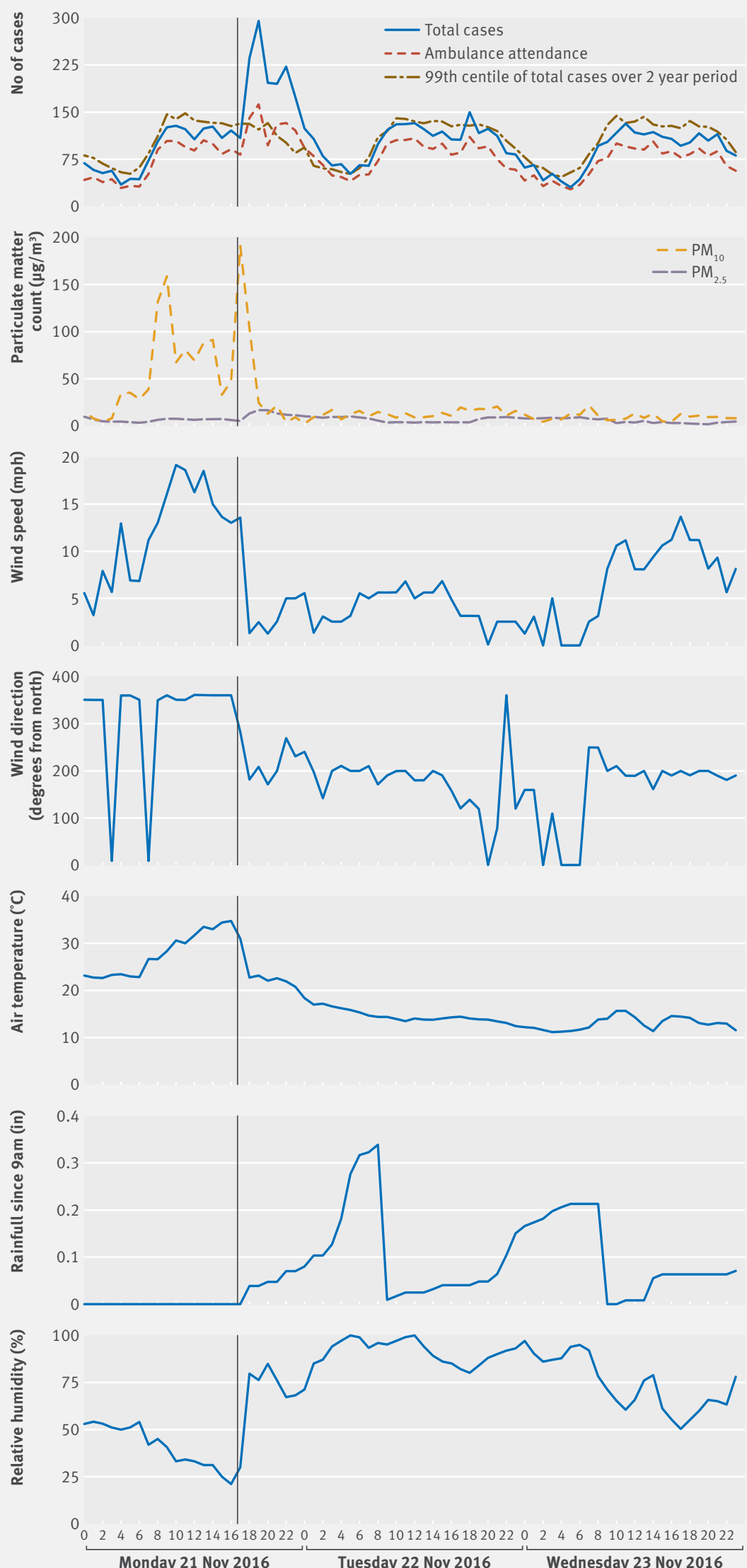

Fig 1 | Hourly emergency medical service caseload and weather patterns. Vertical black line shows the onset of the thunderstorm.

$\mathrm{PM}=$ particulate matter; $\mathrm{mph}=$ miles per hour. thunderstorm asthma was associated with a $149.1 \%$ $(137.1 \%$ to $161.8 \%)$ increase in presentations by patients with pre-existing asthma (table 3). We found a $103.1 \%$ (95.9\% to $110.5 \%$ ) increase in patients using a bronchodilator, compared with $21.3 \%$ (14.2\% to $28.8 \%$ ) in patients using preventive medication. Thunderstorm asthma was associated with an $82.2 \%$ (67.1\% to $98.8 \%)$ rise in out-of-hospital cardiac arrests and a $41.4 \%(28.7 \%$ to $55.5 \%)$ rise in pre-hospital deaths.

\section{Regional variation in the effects of thunderstorm asthma}

We found the highest increases in workload in local government areas to the west and north of Melbourne (supplementary figure S4). But we found increases in demand across Melbourne and surrounding areas (>4600 square miles (12000 $\mathrm{km}^{2}$ ), showing the broad geographical profile of the event.

\section{Discussion}

We describe the impact on emergency services of the world's largest recorded and most severe thunderstorm asthma health emergency. The event was associated with a $41.7 \%$ increase in emergency service caseload and a dramatic increase in cases of acute respiratory distress.

Although some previous studies have described the influence of thunderstorm asthma on health services such as primary care facilities and emergency departments, ${ }^{7}$ 10-13 37 none have examined emergency medical services. These services are recommended as the first point of call for patients with out-of-hospital health emergencies, and understanding their use and the characteristics of patients presenting during such events can assist health planning. We found a 2.5-fold increase in demand for emergency medical services between $6 \mathrm{pm}$ and midnight on the day of the event. This finding supports previous reports in which thunderstorm asthma has been associated with large and sudden spikes in emergency department and general practice presentations. ${ }^{781220}$

Such unprecedented increases in demand place enormous strain on health services. ${ }^{8}$ In Victoria, the emergency medical services implemented a range of demand management strategies after the sudden surge was identified. But the extent, severity, and duration of this event surpassed all expectations. The current state health emergency response plan was drafted for events such as bushfires, heatwaves, and mass casualty events. It was unlikely to be effective for a complex emergency such as thunderstorm asthma, given its broad geographical spread and rapid onset. ${ }^{27}$ Warning of this event may have enabled earlier implementation of demand management strategies, facilitating a more streamlined emergency response and a reduction in the event's wider health impact.

The health impact might also have been reduced through use of preventive measures by patients; this could be achieved through increased future awareness of thunderstorm asthma. For example, thunderstorm 


\begin{tabular}{|c|c|c|c|c|}
\hline & Thunderstorm asthma period $(n=615)$ & Comparator period $(n=1111)$ & $P$ value & Risk ratio $(95 \% \mathrm{Cl})$ \\
\hline Age (years), mean (SD) & $45.1(22.9)$ & $50.4(26.1)$ & $<0.001$ & - \\
\hline \multicolumn{5}{|l|}{ Age (years), n (\%): } \\
\hline $0-14$ & $54(8.9)$ & $84(7.6)$ & 0.4 & $1.16(0.84$ to 1.61$)$ \\
\hline $15-30$ & $117(19.2)$ & $227(20.7)$ & 0.5 & $0.93(0.76$ to 1.14$)$ \\
\hline $31-50$ & $215(35.3)$ & $250(22.8)$ & $<0.001$ & $1.55(1.33$ to 1.81$)$ \\
\hline $51-70$ & $128(21.0)$ & $237(21.6)$ & 0.8 & $0.97(0.81$ to 1.18$)$ \\
\hline$\geq 71$ & $95(15.6)$ & $301(27.4)$ & $<0.001$ & $0.57(0.46$ to 0.70$)$ \\
\hline Missing & 6 & 12 & - & - \\
\hline Male gender, n (\%) & $328(53.4)$ & $539(48.7)$ & 0.06 & $1.10(1.00$ to 1.21$)$ \\
\hline Missing & 1 & 3 & - & - \\
\hline \multicolumn{5}{|l|}{ Pre-existing medical conditions, $\mathrm{n}(\%)$ : } \\
\hline Asthma & $228(37.4)$ & $119(11.0)$ & $<0.001$ & $3.41(2.80$ to 4.16$)$ \\
\hline Other respiratory & $39(6.4)$ & $93(8.6$ & 0.1 & $0.75(0.52$ to 1.07$)$ \\
\hline Missing & 5 & 24 & - & - \\
\hline \multicolumn{5}{|l|}{ Current asthma medications, $\mathrm{n}(\%)$ : } \\
\hline Preventer & $8(1.4)$ & $35(3.4)$ & 0.02 & $0.41(0.19$ to 0.87$)$ \\
\hline Bronchodilator & $156(26.4)$ & $95(9.1)$ & $<0.001$ & $2.91(2.30$ to 3.68$)$ \\
\hline Both & $65(11.0)$ & $63(6.0)$ & $<0.001$ & $1.83(1.31$ to 2.55$)$ \\
\hline Missing & 25 & 65 & - & - \\
\hline $\begin{array}{l}\text { Breathing problems identified in emergency } \\
\text { phone call, } n(\%)\end{array}$ & $345(56.1)$ & $125(11.3)$ & $<0.001$ & $4.99(4.17$ to 5.97$)$ \\
\hline \multicolumn{5}{|l|}{ Dispatch priority, $\mathrm{n}(\%)$ : } \\
\hline Time critical & $527(85.7)$ & $550(49.5)$ & $<0.001$ & $1.73(1.62$ to 1.85$)$ \\
\hline Acute but not time critical & $66(10.7)$ & $442(39.8)$ & $<0.001$ & $0.27(0.21$ to 0.34$)$ \\
\hline Non-acute & $22(3.6)$ & $119(10.7)$ & $<0.001$ & $0.33(0.21$ to 0.52$)$ \\
\hline \multicolumn{5}{|l|}{ Response time (mins), median (interquartile range): } \\
\hline Time critical & 16.7 (11.1 to 26.9$)$ & $11.2(8.6$ to 16.9$)$ & $<0.001$ & - \\
\hline Acute but not time critical & $25.0(13.0$ to 42.3$)$ & $23.6(15.9$ to 36.7$)$ & 0.99 & - \\
\hline Non-acute & $42.9(30.4$ to 61.0$)$ & $39.2(22.4$ to 68.4$)$ & 0.7 & - \\
\hline Paramedic assessed acute respiratory distress, $n(\%)$ & $291(47.3)$ & $43(3.9)$ & $<0.001$ & $12.2(9.0$ to 16.6$)$ \\
\hline Transported to hospital, $\mathrm{n}(\%)$ & $448(72.8)$ & $873(78.6)$ & 0.007 & $0.93(0.88$ to 0.98$)$ \\
\hline
\end{tabular}

asthma commonly occurs in spring, and review of patient asthma action plans by general practitioners in the lead-up to this season may reduce the impact of thunderstorm asthma. ${ }^{28}$ Additionally, given the allergenic nature of the fine respirable particles, prescription of epinephrine injectors for susceptible patients may warrant consideration.

We identified subgroups of patients with the largest increases in demand of emergency services. Our findings support previous studies, which have found increases in emergency department demand by children and young to middle aged adults. ${ }^{12}{ }^{23}$ Our study, however, found that the effect of thunderstorm asthma was delayed in children younger than 15 years. Similarly, our findings support the notion that

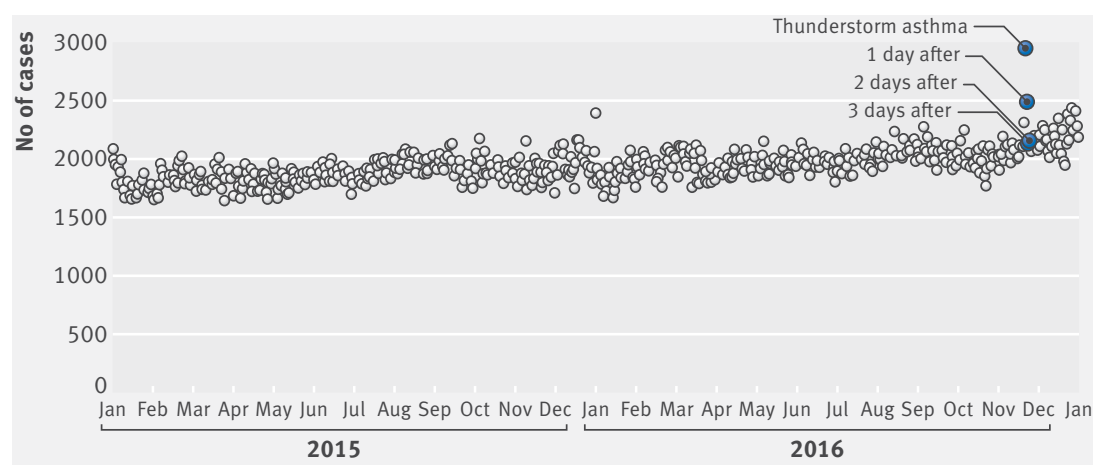

Fig 2 | Daily emergency medical service caseload across the two year study period preventive medication, such as corticosteroids, may be effective in preventing severe asthma attacks related to thunderstorm asthma if taken before the event. ${ }^{6912}$ We found that demand by patients taking preventive medication increased by only $21.3 \%$ on 21 November, compared with a $103.1 \%$ increase among patients taking asthma bronchodilators only. The cumulative demand for emergency medical services among patients taking an asthma bronchodilator alone (incident rate ratio 9.39) was more than five times that of patients taking an asthma preventer (incident rate ratio 1.68).

Finally, we observed a near doubling in cardiac arrests on the day of the event, with the majority reported to be due to a respiratory cause. Ten deaths have been attributed to thunderstorm asthma. ${ }^{27}$ We are not aware of such increases in out-ofhospital cardiac arrest after previous thunderstorm asthma events, although increases in outdoor air pollution in our region have been associated with an increased risk of out-of-hospital cardiac arrest. ${ }^{38}$ The concentration of coarse particles in the air during the thunderstorm asthma event in Victoria was more than double the Australian Environment Protection Measure (Ambient Air Quality) concentration of 80 $\mu \mathrm{g} / \mathrm{m}^{3}$. The concentration of fine particles, however, was only slightly increased. While increasing concentrations of fine particles have been well documented to increase the risk of premature death, ${ }^{39} 40$ the influence of coarse particles and 


\begin{tabular}{|c|c|c|c|c|}
\hline & Immediate effect, IRR $(95 \% \mathrm{Cl})$ & $P$ value & Cumulative effect, IRR $(95 \% \mathrm{Cl})$ & $P$ value \\
\hline \multicolumn{5}{|l|}{ Age (years): } \\
\hline $0-14$ & $1.12(1.07$ to 1.17$)$ & $<0.001$ & $3.11(2.64$ to 3.65$)$ & $<0.001$ \\
\hline $15-30$ & $1.46(1.40$ to 1.52$)$ & $<0.001$ & $2.60(2.24$ to 3.03$)$ & $<0.001$ \\
\hline $31-50$ & 1.39 (1.36 to 1.42$)$ & $<0.001$ & 1.91 (1.76 to 2.07$)$ & $<0.001$ \\
\hline $51-70$ & 1.19 (1.16 to 1.22$)$ & $<0.001$ & $1.03(0.94$ to 1.11$)$ & 0.6 \\
\hline$\geq 71$ & $1.03(1.01$ to 1.05$)$ & 0.009 & $0.97(0.90$ to 1.04$)$ & 0.4 \\
\hline \multicolumn{5}{|l|}{ Gender: } \\
\hline Male & $1.26(1.24$ to 1.29$)$ & $<0.001$ & $1.39(1.29$ to 1.50$)$ & $<0.001$ \\
\hline Female & 1.15 (1.13 to 1.18$)$ & $<0.001$ & 1.61 (1.49 to 1.74$)$ & $<0.001$ \\
\hline \multicolumn{5}{|l|}{ Current asthma medications: } \\
\hline Preventer & $1.21(1.14$ to 1.29$)$ & $<0.001$ & $1.68(1.38$ to 2.05$)$ & $<0.001$ \\
\hline Bronchodilator & 2.03 (1.96 to 2.11) & $<0.001$ & 9.39 (8.24 to 10.7$)$ & $<0.001$ \\
\hline Both & $1.62(1.54$ to 1.71$)$ & $<0.001$ & $2.84(2.35$ to 3.42$)$ & $<0.001$ \\
\hline \multicolumn{5}{|l|}{ Pre-existing medical conditions: } \\
\hline Asthma & 2.49 (2.37 to 2.62$)$ & $<0.001$ & $11.1(9.22$ to 13.4$)$ & $<0.001$ \\
\hline Other respiratory & 1.21 (1.17 to 1.26$)$ & $<0.001$ & 1.89 (1.64 to 2.17$)$ & $<0.001$ \\
\hline Time critical referral from general practitioner & $1.47(1.21$ to 1.80$)$ & $<0.001$ & $0.33(0.16$ to 0.67$)$ & 0.002 \\
\hline Paramedic assessed acute respiratory distress & $5.32(4.98$ to 5.68$)$ & $<0.001$ & $70.5(55.2$ to 90.1$)$ & $<0.001$ \\
\hline Out-of-hospital cardiac arrest & $1.82(1.67$ to 1.99$)$ & $<0.001$ & $1.98(1.45$ to 2.70$)$ & $<0.001$ \\
\hline Pre-hospital death & $1.41(1.29$ to 1.55$)$ & $<0.001$ & $1.56(1.11$ to 2.20$)$ & $<0.001$ \\
\hline Transported to hospital & 1.17 (1.16 to 1.19$)$ & $<0.001$ & 1.31 (1.23 to 1.39$)$ & $<0.001$ \\
\hline
\end{tabular}

aeroallergens on cardiovascular health remains less clear. ${ }^{39}$ Our study indicates that the influence of coarse particles on cardiovascular and respiratory health warrants further investigation.

\section{Limitations}

Our study was retrospective. The capture of patient medications and pre-existing medical conditions was dependent on this information being entered into patient care records and may be under-reported. Hay fever was not routinely recorded, and we were unable to determine the presence or absence of pollen allergy. Because of the high demand for emergency medical services, only $82.3 \%$ of cases had an electronic patient care record available, and numbers for subgroup analyses may be underreported. Although we were able to report paramedic assessment of acute respiratory distress, we were unable to confirm the hospital diagnosis that these patients received. We did not obtain data related to fungal spore counts in the air. Finally, we used environment data from central air quality, pollen, and weather monitoring stations, but patient exposure may have differed across Victoria. Nevertheless, our study is strengthened by the large historical sample size over a two year period.

\section{Conclusion}

An unprecedented thunderstorm asthma event in Victoria was associated with a sudden surge in demand for emergency medical services from patients with severe respiratory distress and those with a history of asthma. Importantly, those using preventive asthma medications were less likely to be affected than those taking a bronchodilator alone. Predictive early warning systems may help to ensure that susceptible people are alerted about future emergencies and to minimise the health impact.
We thank Resmi Nair for her production of the maps presented. Contributors: EA, KS, and MJA conceived the study. EA conducted the initial literature search and drafted the manuscript. EA, EN, and $\mathrm{BP}$ collected the data. EA and ZN performed the statistical analyses; $\mathrm{EA}, \mathrm{ZN}, \mathrm{KS}, \mathrm{SB}, \mathrm{MJA}$, EN, and BP contributed to data interpretation. All other authors reviewed the manuscript and made critical revisions for intellectual property.

Funding: None.

Competing interests: All authors have completed the ICMJE uniform disclosure form at www.icmje.org/coi disclosure.pdf and declare: MJA holds investigator initiated grants from Pfizer and BoehringerIngelheim for unrelated research; other authors had no support from any organisation for the submitted work; all authors had no financial relationships with any organisations that might have an interest in the submitted work in the previous three years; no other relationships or activities that could have influenced the submitted work.

Ethical approval: This study was approved by Monash University Human Research Ethics Committee (\#7739).

Data sharing: Case and patient level datasets are available from the corresponding author on request.

Transparency: All authors take responsibility for the integrity of the data and the accuracy of the data analysis. The manuscript is an honest, accurate and transparent account of the study; no aspects of the study have been omitted.

This is an Open Access article distributed in accordance with the Creative Commons Attribution Non Commercial (CC BY-NC 4.0) license, which permits others to distribute, remix, adapt, build upon this work non-commercially, and license their derivative works on different terms, provided the original work is properly cited and the use is non-commercial. See: http://creativecommons.org/licenses/ by-nc/4.0/

1 Fdez-Arroyabe P, Robau DT. Past, present and future of the climate and human health commission. Int J Biometeorol 2017;61:115-25. doi:10.1007/s00484-017-1413-2

2 Marks GB, Colquhoun JR, Girgis ST. Thunderstorm outflows preceding epidemics of asthma during spring and summer. Thorax 2001:56:468-71. doi:10.1136/thorax.56.6.468

3 Taylor PE, Jonsson H. Thunderstorm asthma. Curr Allergy Asthma Rep 2004:4:409-13. doi:10.1007/s11882-004-0092-3

4 Suphioglu C, Singh MB, Taylor P. Mechanism of grass-polleninduced asthma. Lancet 1992;339:569-72. doi:10.1016/ 0140-6736(92)90864-Y

5 Taylor PE, Flagan RC, Valenta R, Glovsky MM. Release of allergens as respirable aerosols: A link between grass pollen and asthma. J Allergy Clin Immunol 2002;109:51-6. doi:10.1067/mai.2002.120759

6 Wark PA, Simpson J, Hensley MJ, Gibson PG. Airway inflammation in thunderstorm asthma. Clin Exp Allergy 2002:32:1750-6. doi:10.1046/j.1365-2222.2002.01556.x 
7 Howden ML, McDonald CF, Sutherland MF. Thunderstorm asthma-a timely reminder. Med J Aust 2011;195:512-3. doi:10.5694/ mja11.11044

8 Dabrera G, Murray V, Emberlin J. Thunderstorm asthma: an overview of the evidence base and implications for public health advice. O/M 2013;106:207-17. doi:10.1093/qjmed/hcs234

9 Girgis ST, Marks GB, Downs SH, Kolbe A, Car GN, Paton R. Thunderstorm-associated asthma in an inland town in south-eastern Australia. Who is at risk? Eur Respir / 2000;16:3-8. doi:10.1034/ j.1399-3003.2000.16a02.x

10 Bellomo R, Gigliotti P, Treloar A. Two consecutive thunderstorm associated epidemics of asthma in the city of Melbourne. The possible role of rye grass pollen. Med J Aust 1992;156:834-7.

11 Elliot AJ, Hughes HE, Hughes TC. The impact of thunderstorm asthma on emergency department attendances across London during July 2013. Emerg Med / 2014;31:675-8. doi:10.1136/ emermed-2013-203122

12 Davidson AC, Emberlin J, Cook AD, Venables KM. Thames Regions Accident and Emergency Trainees Association. A major outbreak of asthma associated with a thunderstorm: experience of accident and emergency departments and patients' characteristics. BMJ 1996;312:601-4. doi:10.1136/bmi.312.7031.601

13 Wardman AED, Stefani D, MacDonald JC. Thunderstorm-associated asthma or shortness of breath epidemic: a Canadian case report. Can Respir/ 2002;9:267-70. doi:10.1155/2002/728257

14 Forouzan A, Masoumi K, Haddadzadeh Shoushtari M. An overview of thunderstorm-associated asthma outbreak in southwest of Iran. J Environ Public Health 2014;2014:504017. doi:10.1155/2014/504017

15 Packe GE, Ayres JG. Asthma outbreak during a thunderstorm. Lancet 1985;2:199-204. doi:10.1016/S0140-6736(85)91510-7

16 Egan P. Weather or not. Med / Aust 1985;142:330

17 Alderman PM, Sloan JP, Basran GS. Asthma and thunderstorms. Arch Emerg Med 1986;3:260-2. doi:10.1136/emj.3.4.260

18 Waters J, Corbett S, Gibson P. Epidemic asthma surveillance in the New England Region 1990-1992. N S W Public Health Bull 1993;4:100-1doi:10.1071/NB93049

19 Davidson AC, Emberlin J, Cook AD, Venables KM. Thames Regions Accident and Emergency Trainees Association. A major outbreak of asthma associated with a thunderstorm: experience of accident and emergency departments and patients' characteristics. BM/ 1996:312:601-4 doi:10.1136/bmi.312.7031.601

20 Higham J, Venables K, Kupek E, Bajekal M. Asthma and thunderstorms: description of an epidemic in general practice in Britain using data from a doctors' deputising service in the UK. | Epidemiol Community Health 1997;51:233-8. doi:10.1136| jech.51.3.233

21 Pulimood TB, Corden JM, Bryden C, Sharples L, Nasser SM. Epidemic asthma and the role of the fungal mold Alternaria alternata. J Allergy Clin Immunol 2007;120:610-7. doi:10.1016/j. jaci.2007.04.045

22 Al-Rubaish AM. Thunderstorm-associated bronchial asthma: a forgotten but very present epidemic. J Family Community Med 2007; 14:47-51.

23 Erbas B, Akram M, Dharmage SC. The role of seasonal grass pollen on childhood asthma emergency department presentations. Clin Exp Allergy 2012;42:799-805. doi:10.1111/j.1365 2222.2012.03995.x

24 D’Amato G, Cecchi L, Liccardi G. Thunderstorm-related asthma: not only grass pollen and spores. J Allergy Clin Immunol 2008;121: 537-8, author reply 538. doi:10.1016/j.jaci.2007.10.046
25 Levy ML, Bryden C. Thunderstorm Asthma. Brit J Primary Care Nursing. 2007;1:69-71.

26 Losappio L, Heffler E, Contento F, Cannito C, Rolla G. Thunderstormrelated asthma epidemic owing to Olea Europaea pollen sensitization. Allergy 2011;66:1510-1. doi:10.1111/j.1398 9995.2011.02699.x

27 Inspector-General for Emergency Management. Review of response to the thunderstorm asthma event of 21-22 November 2016: Final Report. 2017.

28 Lindstrom SJ, Silver JD, Sutherland MF. Thunderstorm asthma outbreak of November 2016: a natural disaster requiring planning. Med J Aust 2017;207:235-7. doi:10.5694/mja17.00285

29 Department of Health and Human Services. The November 2016 Victorian epidemic thunderstorm asthma event: an assessment of the health impacts. 2017.

30 Eastwood K, Morgans A, Smith K, Hodgkinson A, Becker G, Stoelwinder J. A novel approach for managing the growing demand for ambulance services by low-acuity patients. Aust Health Rev 2016;40:378-84. doi:10.1071/AH15134

31 Victorian Government. State Health Emergency Response Plan. 3rd ed. 2013.

32 Perkins GD, Jacobs IG, Nadkarni VM. Utstein Collaborators. Cardiac arrest and cardiopulmonary resuscitation outcome reports: Update of the Utstein resuscitation registry templates for out-of-hospital cardiac arrest. Circulation 2015;132:1286-300. doi:10.1161/ CIR.0000000000000144

33 Nehme Z, Bernard S, Cameron P. Using a cardiac arrest registry to measure the auality of emergency medical service care. Circ Cardiovasc Qual Outcomes 2015;8:56-66. doi:10.1161/ CIRCOUTCOMES.114.001185

34 de Morton J, Bye J, Pezza A, Newbigin E. On the causes of variability in amounts of airborne grass pollen in Melbourne, Australia. Int Biometeorol 2011:55:613-22. doi:10.1007/s00484-010-0361-x

35 National Asthma Council Australia. Australian Asthma HandbookClassification of asthma medicines 2017. Available from: https:// www.asthmahandbook.org.au/table/show/79.

36 Schäppi GF, Taylor PE, Kenrick J. Predicting the grass pollen count from meteorological data with regard to estimating the severity of hayfever symptoms in Melbourne (Australia). Aerobiologia 1998:14:29doi:10.1007/BF02694592.

37 Hajat S, Goubet SA, Haines A. Thunderstorm-associated asthma: the effect on GP consultations. Br J Gen Pract 1997;47:639-41.

38 Dennekamp M, Akram M, Abramson MJ. Outdoor air pollution as a trigger for out-of-hospital cardiac arrests. Epidemiology 2010;21:494-500. doi:10.1097/EDE.0b013e3181e093db

39 Gold DR, Mittleman MA. New insights into pollution and the cardiovascular system: 2010 to 2012. Circulation 2013;127: 1903-13. doi:10.1161/CIRCULATIONAHA.111.064337

40 Kaufman JD, Adar SD, Barr RG. Association between air pollution and coronary artery calcification within six metropolitan areas in the USA (the Multi-Ethnic Study of Atherosclerosis and Air Pollution): a longitudinal cohort study. Lancet 2016;388:696-704. doi:10.1016/ S0140-6736(16)00378-0

41 Weichenthal S, Lavigne E, Villeneuve PJ, Reeves F. Airborne Pollen Concentrations and Emergency Room Visits for Myocardial Infarction: A Multicity Case-Crossover Study in Ontario, Canada. Am I Epidemiol 2016;183:613-21. doi:10.1093/aje/kwv252

Online supplementary appendix

Supplementary information: supplementary tables S1-S7 and figures S1-S4 